\title{
The Institutionalization of One Man Rule and the Politics of Succession and Patronage in Zimbabwe
}

\author{
Douglas Mpondi \\ Metropolitan State University of Denver, Colorado, USA
}

\begin{abstract}
This paper interrogates the issues of leadership and succession in Zimbabwe and how a political culture of institutionalized power have played in sustaining one man rule in Zimbabwe in both the ruling party and in opposition political parties. Robert Mugabe has been the leader of both Zimbabwe and his party, the Zimbabwe African National Union Patriotic Front (ZANU PF), for more than three decades. Morgan Tsvangirai has been at the helm of the Movement for Democratic Change (MDC) for the past 15 years. Calls for leadership change have divided the MDC and a splinter party MDC Renewal, has been formed as a protest to Tsvangirai's grip on power in the main opposition party. The purging of the voices of dissent in Zimbabwe's two main political parties resembles a revolution devouring its own children, or the case of a hen eating its own eggs. In ZANU PF, different factions are wrestling each other to succeed Mugabe but they have not been open about their struggles for power for fear of backlash from Mugabe. The main question is: Why is there a culture of one man rule in Zimbabwe? How has the Zimbabwean political culture of neo-patrimonialism played a part in long term leadership in Zimbabwean political parties? Is the one man leadership in the MDC an offshoot from the ZANU PF culture of one man rule? What is the relationship between the civilian leadership and the military? The main focus of this paper is on how Mugabe has entrenched an authoritarian system of rule through the manipulation of state structures and a political culture of intolerance, patronage and plunder of national resources.
\end{abstract}

Keywords: Zimbabwe, Mugabe, Tsvangirai, state structures, patronage, neo-patrimonialism

\section{Introduction}

Since gaining independence from Britain in 1980, Zimbabweans have known Robert Mugabe as their only leader. Mugabe gained a new term in controversial elections in 2013. In 2008, when he lost the first round of elections to Morgan Tsvangirai of the opposition Movement for Democratic Change (MDC), Mugabe forced a run-off which he contested alone after the MDC pulled out because of political violence. He declared himself the winner and was quickly sworn before swiftly flying outside the country to Egypt to attend an African Union meeting. However, a power sharing arrangement was made with the MDCs from 2009 to 2013.

Ideologically, Mugabe belongs to the African liberationist tradition of the $1960 \mathrm{~s}$ - strong and ruthless leadership, anti-Western, suspicious of capitalism and deeply intolerant of dissent and opposition (BBC, 2014). Rotberg (2007) argues that Mugabe was "viewed by others as a strongman because of his fight against Western imperialism" (p. 152). Mugabe's political leadership has predatory interests and instincts. It feeds on patronage and the use of the state apparatuses to suppress dissent from opposition parties and civil society groups and

Douglas Mpondi, Assistant Professor, Department of Africana Studies, Metropolitan State University of Denver. 
even in his own Zimbabwe African National Union Patriotic Front (ZANU PF) political party. The purges in ZANU PF after the 2014 congress that included Mugabe's deputy, Joice Mujuru, is a clear testimony on how Mugabe deals with any suspicions and threats to his leadership. He feels secure around people who agree with his policies and pronouncements.

Mugabe has continually blamed the West for Zimbabwe's problems and denies that his corrupt and decadent leadership is behind Zimbabwe's demise from the breadbasket of Southern Africa to a basket case that now relies on food imports to feed a hungry and angry population. Zimbabweans have been victims of xenophobic attacks in neighboring South Africa as they have left their home country because of a deteriorating economic situation and a political environment that does not tolerate divergent views. They prefer to stay in South Africa than return to Zimbabwe to face unemployment and the struggle to survive. Succession issues are not allowed to be discussed openly and the ruling ZANU PF party has been embroiled in factional fighting in preparation to succeed Mugabe. The main opposition party, the MDC has also been involved in succession fights as Morgan Tsvangirai, at the helm of the Movement for Democratic Change since 1999 shows no signs of allowing a young successor to take over. The opposition democratic movement is fractured and fragmented into small parties with personal names and personal interests. They are displaying the same ZANU PF tendencies of "Big Man Rule", personality cults, and hero-worshipping the leadership.

In the 1980's, the signs for Zimbabwe's growth and stability looked encouraging: new government focused on reconstruction, reconciliation and redistribution under an apparently socialist banner carefully tempered by pragmatism. A political priority for the new government, driving years of armed struggle was to reverse seven decades of racially biased inequalities in land and asset distribution, and to bestow fundamental civic and human rights on all its citizens (Moyo, Makumbe, \& Raftopolous, 2000). Mlambo (2014) argues that "Zimbabwe became independent in 1980 full of promise and hope that the future would be one of economic prosperity, political freedom and a generally decent livelihood for all and that the nightmarish past of the colonial period was gone forever" (p. 194). Hammar, Raftopoulos, and Jensen (2003) argue that sovereignty was at the center of the anti-colonial, anti-imperialist rhetoric used by Mugabe and his ZANU PF to counter critics of their revived land revolution and a new brand of authoritarian nationalism. It is a case of nationalism being applied in a belated era, resonating with Frantz Fanon's "pitifalls of national consciousness".

\section{Founding Fathers, Big Man Neo-patrimonial Rule, Personality Cult and Hero Worshipping in Zimbabwean Politics}

Sachikonye (2011) argues that "political parties in Zimbabwe are indeed strongly identified with their founding leaders: Robert Mugabe with ZANU PF, Joshua Nkomo with PF ZAPU, Ndabaningi Sithole with ZANU Ndonga, Edgar Tekere with ZUM, Morgan Tsvangirai with the MDC" (p. 62). These parties have been personalized to an extent of being viewed as the personal property of the leader. The leader is regarded as the face of the political party or the political movement. Without Mugabe, ZANU PF is viewed as weak. He is a feared leader and a strongman whose decisions are final. Tsvangirai has regarded himself as the face of the democratic movement in Zimbabwe despite having made suicidal and disastrous decisions both in the MDC and in the government of national unity from 2009 to 2013. Sachikonye (2011) further claims that "there is often a strong will on the part of the founding leader to perpetuate his or her position... congresses and annual conferences are not genuine vehicles for discussion or negotiation of political succession” (p. 62). 
Mugabe has been in power in Zimbabwe for the past 35 years. His tenure in office has been a result of personal rule and use of the state apparatuses, (the military and the police) the rigging of elections to stay in power:

There is a strong element of personalization of leadership in the Zimbabwean political landscape, and this is in line with the trend in most African political parties. In Zimbabwe, there is a campaign for Mugabe to be the country and party President for life, often referred to a God-sent, as God's second son, as a gift from God. Other symbols of personality worship include activities of the 21st February Movement that celebrates Mugabe's birthday every year, and the emblazoning of his face on caps, t-shirts, and dresses. (Sachikonye, 2011, p. 62)

Although there are registered opposition political parties in Zimbabwe, in reality, Zimbabwe is a de facto one party state and has a president-for-life. Mugabe lost the presidential elections in 2008 against Morgan Tsvanagirai of the MDC but resorted to violence to retain power. The government of national unity (GNU) with the MDCs was a political gimmick by Mugabe to buy time while re-strategizing on how to regain total control of both the state and government. Elections were held in 2013 without any electoral reforms.

Towards the end of the 1990s, the political economy of Zimbabwe saw a decline with the value of the Zimbabwean dollar becoming weaker against major currencies. This started with the compensation of the war veterans in 1997 with unbudgeted funding. That day became known as the "Black Friday" as the Zimbabwean dollar plummeted to unprecedented levels. According to Kairiza (2009) "the payouts amounted to almost three percent of GDP at the time and this had the immediate effect of inflating the budget deficit at the end of 1997 by 55 percent from the 1996 levels" (p. 4). Zimbabwe's participation in the DR Congo war did not help as the Zimbabwean government was paying for the war expenses expecting returns from mineral concerns promised by the Kabila regime. Mlambo (2013) believed that the turning point of the Zimbabwe political landscape was when ZANU PF faced a strong challenge from the MDC:

The year 2000 marked the beginning of a turbulent time in Zimbabwean politics, one characterized by mounting political opposition to ZANU PF rule and by the increasing political repression of opposition forces, particularly the MDC which presented the strongest challenge to the ruling party. It witnessed a referendum, three controversial elections and growing use of violence and abuse of human rights by ZANU PF structures. (p. 231)

There has been an increase in opposition supporters being killed or disappearing before, during and after elections since 2000. The level of violence after the 2008 elections forced Mugabe to go to the negotiating table after pressure from the regional organization, the Southern African Development Community (SADC). Mugabe's prolonged stay in power has been sustained by rigging, intimidation of voters and the continued use of state machinery and the militarization of state institutions.

Ndlovu-Gatsheni (2009) argues that the Zimbabwean debate has polarized scholarship into what he calls "Mugabeism",

"Zimbabwe will never be a colony again-Blair keep your Britain and I will keep my Zimbabwe”-Mugabeism. What is termed "Mugabeism" is a summation of a constellation of political controversies, political behavior, political ideas, utterances, rhetoric and actions that have crystallized around Mugabe's political life. It is a contested phenomenon with the nationalist aligned scholars understanding it as a pan-African redemptive ideology opposed to all forms of imperialism and colonialism and dedicated to a radical redistributive project predicated on redress of colonial injustices. A neoliberal-inspired perspective sees Mugabeism as a form of racial chauvinism and authoritarianism marked by antipathy towards norms of liberal governance and disdain for human rights and democracy. ( p. 1139) 
It is a historical fact that Mugabe played a crucial role during the liberation struggle for Zimbabwe, but he was not alone. Unsung and unknown heroes and heroines sacrificed their lives for the liberation of the country. Zimbabwe is not a personal property of individuals but a country that belongs to all Zimbabweans.

Zimbabwe is a classic case of neo-patrimonialism. Government and political party appointments reflect patronage, regionalism, and sometimes ethnic inclinations. Englebert and Dunn (2013) instructively define neopatrimonialism as:

An ensemble of practices and features of African political systems-personal rule and the personalization of politics, patronage, the lack of distinction between public and private realms, institutional weakness, coexistence of bureaucratic and informal politics, corruption... The person of the chief is the most crucial piece of the patrimonial puzzle. He is the central defining character of the system. There is thus a large element of reciprocity in a patrimonial system: the main patron uses his authority and legitimacy derived from his dominant family position to appoint others to positions of authority, from which they can gather resources for themselves in exchange for their loyalty and for transferring some resources back to him. (p. 130)

The land reform in Zimbabwe, whilst it redressed racial and colonial historical imbalances in terms of land ownership, has also tended to benefit mostly people connected to the ruling party and to the ruling elite. Some people have lost their farms and properties after being expelled from the party or disagreeing with the top ZANU PF leadership. Land was also used a political tool to exclude citizens from enjoying the fruit of the liberation struggle.

Zimbabwe is defined in personal terms as an entity that belongs to the person of the president. Government ministers, top security chiefs, and judges have openly pronounced their allegiance to Mugabe. Even those who were purged from ZANU PF after the December 2014 Congress still sing praises to the president. One plausible explanation is that they want to protect their wealth that they got through the patronage system. Some government and party officials who were expelled fear that their farms and other properties will be confiscated because of their alleged support of the former Vice President Joyce Mujuru. If the land distribution exercise was transparent, why then take away the farms from former Ministers and Members of Parliament who belong to the "wrong basket", the Mujuru faction? Mugabe's leadership and prolonged stay in power has survived on patronage and clientilism (Mpondi, 2012).

The political system in Zimbabwe revolves around the personality of the president, "the personal ruler, the all-powerful president whose words sometimes matter more than the country's constitution" (Englebert \& Dunn, 2013, p.132). Mugabe has openly proclaimed that he would want to see a judge who is brave enough to hear a case brought to the courts against him by his political opponents and adversaries. The country's laws are subverted by such utterances from a head of state who views himself as above the law. Mawere (2015) argues that there is an exceptionalism that has pervaded the Zimbabwean body politic for the past 40 years:

What is Zimbabwean political exceptionalism? How has it evolved? In what way does it impact the character and personality of Zimbabwean politics? In its simplest form, Zimbabwean political exceptionalism refers to the presumed special character and personality of the LEADER as uniquely gifted and skilled to preside over the nation's affairs. Indeed, Zanu PF has had President Mugabe as its leader for almost 40 years and, within the party, he remains a towering figure with no equal. The recent developments that have seen his former deputy, Hon. Joice Mujuru, and persons perceived to be her followers, thrown outside the political cockpit of both the party and State have clearly demonstrated the inherent exceptionalism that has dominated political thinking in Zimbabwe. (p. 1) 
Mugabe is feared by his own party members and succession issues have seen the purging of those perceived to be on the Mujuru camp. There are now camps fighting for power within ZANU PF, the "weevils" faction that is close to Mugabe, the "gamatox" faction that is believed to support former Vice President Mujuru, the generation 40, young Turks fighting for the control of the party fronted by the Political Commissar, Saviour Kasukuwere. This is not surprising as "factionalism is a typical feature of neopatrimonial systems" (Engelbert \& Dunn, 2013, p. 133). The struggle for power in ZANU PF and in Zimbabwean politics in general is mainly about inclusion and exclusion from neopatrimonial distribution because:

Neopatrimonialism suffers from its polycentric nature: there are too many patrons, too many factions, too many endlessly reproduced and renegotiated reciprocal exchanges, with the result that economic operators cannot factor the costs of the system in and remain vulnerable to its unpredictability. (Englebert \& Dunn, 2013, pp. 140-41)

In Zimbabwe, there are too many factions and too many centers of power in both the ruling ZANU PF and the opposition MDCs. Allegiance to the leader of the party is rewarded with position, power and wealth. Those against the leader of the party are purged and expelled from the party and any benefits they received are subject to review.

\section{Leadership and Opposition Political Parties in Zimbabwe}

A personality cult on a similar scale is noticeable in the opposition MDC which has Tsvangirai's name at the end MDC-T. Tsvangirai claims that he is the face of the movement and without him nobody has the credentials to remove Mugabe from power. Tsvangirai is a former union leader who helped found the MDC in 1999. As MDC leader he has faced intimidation, treason charges, physical assault and at one stage was charged with plotting to kill Mugabe. He first took on the government when, as s Secretary General of the Zimbabwe Congress of Trade Unions, he led a series of strikes against high taxes in the late 1990s. Tsvangirai once declared that his strategy to unseat Mugabe was to wait until the president mismanaged the economy to such an extent that he was forced out of office. This long-term approach may have helped to prevent the split in Zimbabwean society from developing into civil war, but Mugabe's grip on power shows no sign of loosening and even some of Tsvangirai's supporters now suggest that he has been out manoeuvred by the president and his allies.

Opposition political parties in Zimbabwe are fractured, institutional weak, and fragmented. Personal egos and pursuit for power rather than serving the people's interests has become the norm in the opposition parties in Zimbabwe, especially the MDC. The MDC comes in different names and colors, personifying the name of the leader: MDC-T for Tsvangirai, MDC-N for Welshman Ncube, MDC Renewal for Tendai Biti. What that means is that the party belongs to an individual and if that individual is no longer interested in the party or is replaced, a new name has to be created. Lovemore Madhuku has been the leader of the former civil society organization, the National Constitutional Assembly (NCA) for more than a decade. The NCA started as an advocacy organization for a new and democratic constitution in Zimbabwe. After a new constitution was drafted in 2013 which the NCA did not participate in, the NCA was transformed into a political party as a sign of the times and possibly to make itself more relevant to the new political dispensation. Madhuku retained the presidency of the new party and questions have been asked about the democratic nature of Zimbabwean civil society organization. A relic of the one party state era, personality cults are an outdated aspect of authoritarian leadership and politics. Thus Zimbabwean political parties have not been very active agents in the 
incubation of democratic civic and political cultures (Sachikonye, 2011). There is a single-minded focus on the pursuit of power, tendency and weakness for personality cults around their leaders as well as for factionalism.

\section{Militarization of the State and Patronage System}

The military-security complex in Zimbabwe (police, army, Air-force, prison service, intelligence service) with deepening authoritarianism, the state apparatuses became deeply involved in state administration and party politics as well as in business. In Zimbabwe, the military-security complex played a leading role in buttressing Mugabe in elections held in 2000, 2002, 2005, 2008, and 2013 when his political fortunes were shaky (Sachikonye, 2011, p. 33). The security chiefs have openly declared their support for Mugabe and claimed that they would not salute anybody who has not fought the liberation war. Tsvangirai was the target of this declaration and when he won the presidential elections in 2008, it was the military that helped Mugabe to go for a second round of elections through the Joint Operations Command (JOC). Sachikonye (2011) clearly postulates that "command posts in the Zimbabwe National Army (ZNA) from position of Colonel upwards have been political appointments directly approved by President Mugabe" ( p. 33).

Mugabe has relied upon the military-security complex to frustrate the will of the citizens during the period of elections. He has appointed key military personnel to run the Electoral Supervisory Commission which organizes the elections. The military-security complex set up a National Command Centre (NCC) which collated the election results provoking charges of rigging and manipulation by the opposition and some election observer teams. The military-security complex was credited for running a violent run-off election campaign after Mugabe lost the first round in March 2008. The military-security complex in Zimbabwe has been increasingly involved in running government ministries and departments, parastatals, commissions, and various ad hoc military-style operations such as Operation Murambatsvina (Restore Order) in 2005, Operation Mavhotera Papi (Who did you vote for) in 2008 (Sachikonye, 2011, p. 33).

There were a number of military officers appointed as ministers, judges, permanent secretaries, ambassadors, directors and board members of parastatals. These appointments reflected the extensive patronage at the president's disposal to reward and retain loyalty, securing political tenure for Mugabe, plundering of national resources, accumulation, and self-enrichment. Sachikonye (2011) postulates that "the entry into politics of the military has far-reaching significance and repercussions for the structure and administration of the state especially during the period between 2000 and 2008" (p. 34). The military has helped to prolong Mugabe's stay in power because they also benefit from propping up his regime. Zimbabwe is run by a military-junta with a civilian President.

\section{State and Party Structures}

ZANU PF is both the ruling party and the party with the majority in parliament. The party and the state are viewed as one entity:

The ZANU PF reigns supreme in the governance sphere-it is difficult to disentangle party structures from state structures regarding the allocation of state resources; there is an inter-penetration of the two sets of structures, especially at local levels. The Zimbabwean experience of fusing party-state structures is reminiscent of structures in communist/socialist states in Eastern Europe and China. (Sachikonye, 2011, p. 35) 
State resources in Zimbabwe are allocated along party lines. Food has also been used as political tool by the Mugabe administration by excluding opposition supporters from receiving food aid from the government. It is as if the food is coming from party coffers and not state institutions.

Mugabe has also stayed in power for too long by controlling the security structures and also the media. Licenses were also given to pro-Mugabe supporters and clients-patron-client network. Repressive legislation, the Access to Information Protection and Privacy Act (AIPPA) and the Public Order Security Act (POSA) entrenched intimidation, and tightened the hold of the ruling party over state mechanisms of arrest, incarceration, violence and control of populations and resources. The laws criminalize citizens for criticizing the office of the Presidency. Mlambo (2014) aptly sheds light on the Zimbabwean situation since the turn of the millennium:

The first decade of the new millennium found Zimbabwe in the throes of a severe political, economic and social crisis that reversed the gains and achievements of the 1980s and deepened the problems and challenges facing the majority population, which had begun in the 1990s with ESAP. The crisis also turned the country into a pariah state, as human rights violations and political intolerance led to worldwide condemnations of the country's ruling elite, and a chaotic land reform programme turned the region's erstwhile breadbasket into a land dependent on food aid. (p. 231)

It was the year 2000 that Mugabe and his ZANU PF party tasted defeat in a referendum and also lost significant parliamentary seats to the new opposition party, the MDC. Opposition to the Mugabe administration was viewed as declaring war against both the party and government. Protesters were labeled "enemies of the state" who were bent on reversing the gains of the liberation struggle. It is a truism that the food shortages in Zimbabwe in the last decade were also propelled by the chaotic nature of the fast track land reform program.

\section{Conclusion}

The current situation in Zimbabwe has reinforced an authoritarian and increasingly repressive rather than democratic mode of rule. The Zimbabwean leadership elites have relied on patronage and corruption to stay in power. Factional fights are a result of power struggles within the Zimbabwean political landscape. The Zimbabwean leadership is more concerned with power than serving the interests of the citizens.

Zimbabwe is now the largest importer of food in the SADC region because of poor agricultural policies, drought, and the politicization of the land reform program. Fifteen years after the fast-track land program, a land and agricultural revolution would have taken Zimbabwe back to its breadbasket status. While radical land reform was necessary, the methods used in the fast track program have been erratic, inconsistent, and destructive to the economy and the well-being of millions of citizens. Large swaths of land have not been utilized and lying idle as the small holder farmers given land did not have sufficient inputs to kickstart sustainable agriculture. Top government officials tended to be the beneficiaries of the Reserve Bank of Zimbabwe inputs program whilst the ordinary people had to fend for themselves. Banks could also not give people loans where there is no collateral as the state owns the land. Mugabe has been on record saying "nobody will die of hunger". Zimbabwe relies now on handouts from Non-Governmental Organizations (NGOs) and friendly countries to offset its budget deficit. The Zimbabwean finance minister has been continuously on the road holding a begging bowl to the IMF and World Bank, China, South Africa, Africa Development Bank and the immediate result has been Memorandums of Understanding (MOUs).

The once vibrant Zimbabwean health and education sectors are now decadent and providing poor services to the people. People are poor and cannot afford basic commodities for the entire month. Road and railway 
infrastructures in Zimbabwe are dilapidated and in a sorry state, bringing questions of where and how the proceeds from diamonds and platinum are being utilized. Government-owned parastatals are among the worst performing companies in Zimbabwe with non-payment of workers' salaries and owing local creditors and international financial institutions. Zimbabwe is regarded as an unfriendly economic destination for foreign direct investments (FDIs). It is mostly those in government and connected to the political elites through patronage and clientilism who are benefitting from the economic chaos in Zimbabwe. There is no value addition and beneficiation to the ordinary man in the street. Zimbabwe's economy is now fully informalized and everyone has been turned into a vendor as the economic environment is about buying and selling even for the employed as the wages are not enough to last for a week let alone a month. Companies are closing and Zimbabweans have been losing jobs on a daily basis. The result has been continued migration to other countries in search for greener pastures.

Zimbabweans would rather face the wrath of xenophobic attacks in neighboring South Africa than face the daily struggles of trying to survive in Zimbabwe. In a country where more than $80 \%$ of its citizens are unemployed, it makes sense that Zimbabweans are determined to stay wherever they are, than coming back to a country that is on the brink of collapse. The ZimAsset document is an excellent example of a white paper document "high sounding nothing", its objectives are ambitious for an African renaissance and revival but the reality on the ground is antithetical to economic sustainability and Pan-African ideals.

Since Mugabe won the 2013 elections, the economy of Zimbabwe has spiraled downwards and the future looks bleak for the ordinary Zimbabwean. The state of the economy can only change for the better with a transparent leadership that is sincere to the electorate. Zimbabwe's two best performing companies are Econet and Delta, a mobile telephone company and beverage company respectively. The indication is that Zimbabweans are drinking and texting. In an informal economy, it is imperative to be always connected in order to know where to get the means to survive. The Zimbabwean case is a case of a failed leadership and an entrenchment of patronage and corruption in the guise of empowerment and indigenization. Zimbabwe needs institutions that can sustain both leadership change and development. Implementation of policies and respect of the rule of law are challenges in Zimbabwe. Zimbabwe desperately and imperatively requires a transparent leadership that respects the rule of law and the will of the citizens. The economy of Zimbabwe will improve through both economic and political solutions. The shortest route to the future is via the past, learning from the mistakes made and implementing new ideas. Zimbabwe has the human and natural resources to transform the condition of the economy and create more jobs for a restless and unemployed population. Zimbabwe should not borrow leadership from the past but from the future. A country with one of the highest literacy rates in Africa should build sustainable institutions that will help forge a brighter future for the coming generations.

\section{References}

BBC. (2015, April 14). Zimbabwe country profile-overview. Retrieved June 9, 2015, from http://www.bbc.com/news/world-africa-14113249

Englebert, P., \& Dunn, K.C. (2013). Inside African politics. Boulder: Lynne Rienner Publishers.

Hammar, A., Raftopoulos, B., \& Jensen, S. (Eds.). (2003). Zimbabwe's unfinished business: Rethinking land, state and nation in the context of crisis. Harare: Weaver Press.

Kairiza, T. (2009). Unbundling Zimbabwe's journey to hyperinflation and official dollarization. GRIPS Policy Information Center. Discussion Paper: 09-12. Retrieved August 19, 2015, from http://www.grips.ac.jp/r-center/wp-content/uploads/09-12.pdf

Mawere, M. (2015). The politics of exceptionalism: The Zimbabwean case study. Retrieved June 26, 2015, from http://www.newzimbabwe.com/columns-21134-Mugabe+and+the+politics+of+exceptionalism/columns.aspx 
Mlambo, A. S. (2014). A history of Zimbabwe. New York: Cambridge University Press.

Moyo, S., Makumbe, J., \& Raftopoulos, B. (2000). NGOs, the state, and politics in Zimbabwe. Harare: Sapes Books.

Mpondi, D. (2012). The struggle for nationhood and citizenship in Zimbabwe. In D. Kaulemu (Eds.), Imagining citizenship in Zimbabwe (pp. 50-58). Harare: Konrad Adenauer Stiftung.

Ndlovu-Gatsheni, S. J. (2009). Making sense of Mugabeism in local and global politics: So Blair keep your England, and let me keep my Zimbabwe. Third World Quarterly, 30(6), 1139-1158.

Rotberg, R. I. (2007). Africa's troubled leadership and what to do about it. The Fletcher Forum of World Affairs Journal, 32(2), 149-164.

Sachikonye, L. (2011). Zimbabwe's lost decade: Politics, development and society. Harare: Weaver Press. 